\title{
Teaching style, learning behaviour and learning achievement on economic education student of Universitas Negeri Padang
}

\author{
Eka Septianti Laoli ${ }^{1}$, Efrizal Syofyan ${ }^{2}$ \\ ${ }^{12}$ Universitas Negeri Padang, Padang - Indonesia, (ekaseptianti_laoli@yahoo.co.id)
}

\begin{abstract}
The background in this research is student achievement not yet reached the level of achievement maximal. Of which $74 \%$ of students have a GPA of $<3.50$. The purpose of this research is to analyze the effect of lecturer teaching style, and student learning behavior toward student achievement. This type of research is a quantitative descriptive. Population in this research is student of semester V of Economic Education Program of Universitas Negeri Padang which amounted to 124 people with propotional random sampling technique. The results showed that: 1) There is a positive and significant effect between teaching style lecturers and learning behaviour towards on the student achievement 2) There is a positive and significant effect between teaching styles lecturers towards on the student achievement, 3) There is a positive and significant effect between learning behaviour on student achievement.
\end{abstract}

Keywords: teaching style, learning behaviour, achievement

This is an open access article distributed under the Creative Commons 4.0 Attribution License, which permits unrestricted use, distribution, and reproduction in any medium, provided the original work is properly cited. @2018 by author and Faculty of education Universitas Negeri Padang.

\section{Introduction}

One of the goals of higher education in Indonesia is to develop the potential of students to become human beings who believe and be cautious to God Almighty and have noble character, healthy, knowledgeable, capable, creative, independent, skilled, competent, and cultured for the benefit of the nation. Developing the potential of human resources in line with the improvement of the quality of national education that refers to the National Curriculum Framework Indonesia (KKNI) for higher education. The Indonesian National Curriculum Framework (KKNI) is the foundation in developing the curriculum so as to achieve the expected results. KKNI is a framework of competency qualification gap that can match, equalize and integrate between the field of education and the field of job training and work experience in the framework of giving recognition of work competence in accordance with the provisions of work in various sectors. KKNI is a manifestation of quality and national identity of Indonesia related to the national education and training system owned by Indonesia. The quality of human resources (HR) can be improved through learning activities. According to Iru (2012), "learning is a process of interaction of teaching and learning in a certain condition involving several elements, both extrinsic and intrinsic elements inherent in students and lecturers including the environment". In order to 
realize its objectives, the quality of the learning process process needs to be improved. Through the quality of learning can illustrate both the poor results achieved by students in the learning process that has been implemented by educational institutions. Educational institutions can be said to succeed if it can change the behavior of students in accordance with established goals and can produce productive human resources.

In summary can be understood that is to realize the knowledge by improving student achievement through improving the quality of lecturers, facilities of good infrastructure, comfortable learning environment (Novandi and Djazari, 2011). The problem in this research is student achievement which still pertained not yet reached the level of achievement maximal. Of which $74 \%$ of students have a GPA of $<3.50$. This can be expected to occur due to the teaching styles displayed by the lecturers seem rigid and monotonous, such as a voice that is not heard clearly, the eyes focus on one point, facial expression, limb movements so as not to facilitate students to understand the subject matter (Marmah , 2014). The importance of this study to determine the extent of influence of teaching styles of lecturers and student learning behavior to the achievement of learning either partially or simultaneously

In carrying out their duties, each lecturer has its own style to convey the learning Appearance of lecturers in teaching is very important because the lecturer is like the model, every appearance, behavior, sound or way of walking very attention of the student, so the lecturer must be able to keep the appearance in front of the students, students feel comfortable seeing it, so that a lecturer should use an interesting teaching style for their students so that students are not bored in following the lesson. The purpose of holding a variety of teaching according to Djamarah (2010), among others to improve and nurture students' attention, motivate students, shape positive attitudes of teachers and schools, deliver possible individual choice and learning facilities, and encourage students to learn. Also when lecturers have shown good teaching styles, but students do not have good learning behaviors such as students not focusing on lecturers' explanations, lack of reading habits and visiting perputakaan, as well as lack of preparation for exams which will impact on achievement less than the maximum (Milligan et al, 2014). Achievement arises from the ongoing practice of sharing knowledge undertaken in the learning process (Lau, 2014). Students are required to continue to exercise the knowledge they have in order that the Value gained in the form (GPA) should be supported by a full understanding of the overall material being studied (Mattern, 2005). Teaching style may be defined more precisely as "a teacher's personal behaviors and media used to transmit data to or receive it from the learner (Alhussain, 2012). A good teaching style can create a more attractive learning environment for students so as to enhance students' readiness and learning ability (Shaari, 2014).

Learning in colleges applies learning to adults where more university students are required to selfregulate without relying on the presence of lecturers. Students should be aware to have an adult learning behavior so as to be able to organize themselves to learn without coercion (Tennant, 2012). In the process of learning, it is very important that students have learning behavior that is the habit and interest to repeat the lessons he has received from his lecturer. The student can not rely on what he or she has gained without conscious effort to repeat the lesson. In fact, not only repeat, it would be better if when repeating the lesson he read many other reverence, either by reading a book or asking with his professor or his friend. These things are very helpful for students to keep the material studied lasted in the memory of students and when students are faced with the exam, the students are no longer confused to answer questions given, or when the teacher asked the previous lesson then the student can answer it. From the above description, it is assumed that student learning behavior has an effect on student's economic learning outcomes. The better the student's learning behavior is expected better the student's economic 
learning outcomes. Student learning behavior is a process of learning that lived, experienced, and also a learning activity from various sources of learning in the environment (Dimyati and Mudjiono, 2006)

Hypothesis in this research is as follows:

H1: There is effect between teaching style of lecturer and student's learning behavior toward learning achievement.

H2 : There is effect between teaching style of lecturer to learning achievement.

H3 : There is effect between teaching style of lecturer and student's learning behavior toward learning achievement.

\section{Method}

The type of this research is quantitative descriptive research. This research was conducted on Student Semester V Economic Education Program State University of Padang with the number of population 124 people and sample of 95 people by using technique of Propotional Random Sampling. The data used are primary data and secondary data. Included in the primary data is the distribution of questionnaires to students and which includes secondary data that is the student's IPK data obtained from the computer center of Universitas Negeri Padang.

Data collection techniques used in this study are as follows collecting data with questionnaires where the questionnaire that has been prepared spread directly to the respondent, and it would be better if researchers accompany the respondent during filling so that when there is a question in the questionnaire difficult to understand then respondents can directly ask. Then the interview is done through the process of question and answer interaction between the researcher with the respondent as the resource person as the interviewee. And lastly in the form of observation and recording systemically to the symptoms that appear on the object of research.

Before the research, validity test was conducted on the questionnaire that had been prepared using the help of SPSS version 17.0. Once the validity level is determined proceed with the reliability test using the Cronbach Alpha coefficient. Normality test is done by using Kolmogrov-Smirnov which aims to see whether the distribution of data is on the normal curve. Multicolinearity test using VIF (Variance Inflation Factor) method. by looking at (1) the opponent's toleranced value (2) VIF (variance inflation factor). The common cut off values used to indicate the presence of multicolonierity are tolerance values $<0.10$ or equal to VIF $>10$. Heteroscedasticity is used to determine whether or not there are deviations from classical assumptions. Heteroscedasticity is the presence of variant inequality of the residual for all observations in the regression model. In this research to know whether or not heteroscedasticity used Scatterplot chart method between the predicted value of the dependent variable is ZPRED with residual SRESID. The next step is to test the regression coefficient analysis to test the hypothesis by using multiple linier regression analysis / multiple regression analysis. In this study contains the elements of test coefficient of determination $(\mathrm{R})$, simultaneous test $(\mathrm{f})$, partial test $(\mathrm{t})$.

Validity test in this research is done by Pearson Validity correlation with product moment technique that score of each item correlated with total score. Based on the result of research known that each indicator of lecturer teaching style variables, learning behavior and achievement have significance value $<0,05$. The result of reliability test of teaching style of lecturer, learning behavior and learning achievement shows that Cronbach Alpha> 0,60 value is 0,655; 0,649; 0.631; 
The result of the normality test which means that the result of normality test with Normal Probabilitty Plot shows that the data spreads around the diagonal line, then the regression model meets the assumption of normality. Multicollonearity test, multicolinearity detection in this research is done by VIF method. If the VIF value of each predictor is about 1 then it can be concluded that the model is not exposed to multicolinearity. The results of multicollinearity test in this study can be known as follows. The result of multicollinearity test with VIF method get VIF value about 10 with VIF lecturer teaching style (X_1) equal to 1,101, learning behavior equal to 1,101, it means that all independent variable does not occur multicollinearity.

A homogeneity test was conducted to see if the data obtained came from a homogeneous sample. The guidelines in the homogeneity test are: if sig $\geq 0.05$ means the data spread homogeneously. If sig $<0.05$ means the data does not spread homogeneously. The homogeneity test in this study was performed using SPSS version 17.00 showing the same homogeneous spread data, for lecturers teaching style variables (X1) obtained by 0.667 with a significant significance of 0.05 , it is stated that teaching style of lecturers is homogeneous, for learning behavior variable (X2) is 0.791 with significant value greater than 0,05 then stated data of learning behavior is homogeny.

The result of calculation by using computer statistic program SPSS version 17.0 have results from multiple linear regression analysis can be seen in the following table:

\begin{tabular}{|c|c|c|c|c|c|}
\hline \multirow[t]{2}{*}{ Model } & \multicolumn{2}{|c|}{ Unstandardized Coefficients } & Standardized Coefficients & $\bar{t}$ & Sig. \\
\hline & $\bar{B}$ & Std. Error & Beta & & \\
\hline 1 (Constant & 1.043 & .322 & & 3.239 & .002 \\
\hline$x_{1}$ & .016 & .002 & .589 & 7.775 & .000 \\
\hline$x_{2}$ & .014 & .004 & .259 & 3.374 & .001 \\
\hline
\end{tabular}

The table above shows the results of multiple linear regression analysis can be written as follows: $\mathrm{Y}=1.043+0.016 \mathrm{X} 1+0.014 \mathrm{X} 2+\mathrm{e}$

In the equation above shown the influence of independent variable $(X)$ to the dependent variable $(Y)$. The meaning of the coefficient of regression is as follows: (1) Constant value of 32.133 That is, if teaching style of lecturer and learning behavior equal to 0 (zero), then student learning achievement of 1,043 (2) Coefficient value X_1 0.016 That is, teaching the lecturer is 1, the student's learning achievement increases by 0.016 with the assumption that other variables are constant (ceteris paribus), (3) coefficient valueX_2 0.014 That is, if the increase of learning behavior is 1 , then the student's learning achievement increases by 0.014 assuming another variable is constant (ceteris paribus).

Regression result obtained on statistical test of $R$ square computer (Coefficient of Determination) 0,507 means dependent variable $(\mathrm{Y})$ in model that is learning behavior explained by independent variable that is teaching style of lecturer and learning behavior equal to $50.7 \%$ while the rest equal to $49.3 \%$ explained by other factor outside the model. The result of calculation by using SPSS Statistics 17 computer statistic program is obtained by simultaneous statistical test for free variable of teaching style of lecturer (X_1), learning behavior (X_2), to the dependent variable of learning achievement (Y) 


\begin{tabular}{lllllll}
\hline Model & $\begin{array}{l}\text { Sum } \\
\text { Squares }\end{array}$ & of & Df & MeanSquare & F & Sig. \\
\hline Regresion & 4.493 & 2 & & 2.246 & 47.358 & $.000^{a}$ \\
Residual & 4.364 & 92 & .047 & & \\
Total & 8.857 & 94 & & & & \\
\hline
\end{tabular}

Based on the above table it can be seen that the value Ftest 47.358> Ftable 2.67 and significant value of 0.000 . The value of $\operatorname{Sig}<\alpha$ is $(0,000<0.05)$. Then $H_{-} \_$is rejected, $\mathrm{H} \_$a accepted. Means the teaching style of lecturers, and learning behavior simultaneously have a significant influence on student achievement.

Based on the results of data analysis is known that the teaching style of lecturers have a significant positive effect on learning achievement. This is shown from the results of partial hypothesis test shows that the teaching style of lecturers has a significant level of $0.000<0.05$ and positive value of $t_{-}$test, because the level of significance is smaller than 0.05. The test results show that H_a accepted which means teaching style of lecturers have a positive and significant impact on student achievement.

Based on the results of data analysis, it is known that learning behavior has a significant positive effect on the level of learning achievement. This is shown from the results of partial hypothesis testing showed that emotional intelligence has a significant level of $0.001<0.05$ and positive value of $t$ test, because the level of significance is smaller than 0.05 . The test results show that H_a accepted which means learning behavior has a significant influence on learning achievement.

\section{Result and Discussion}

Effect of Teaching Style of Lecturer and Student Learning Behavior on Student Learning Achievement

This result shows that the determinant coefficient is adjusted $R$ square $=0,507$ which means the influence of teaching style and learning behavior toward student achievement is $50,7 \%$, the rest $49,3 \%$ influenced by other factors like physical condition, talent, interest, intelligence, motivation and others. The results showed that: There is a positive and significant effect between teaching style lecturers and learning behaviour towards on the student achievement

The results of this study also supported by research conducted by Lu, et al (2016) states that the students' perceptions of how to teach teachers during learning will increase the interaction between teachers and students so as to improve student semester test results. Also research conducted by Erdogan, Bayram, and Deniz (2008) states that students' attitudes in addressing their environment will increase their exposure to learning outcomes that spur students to act actively in learning.

\section{Effect of Teaching Style of Lecturer to Student Achievemen}

The result of this research is data, the calculation of multiple regression analysis shows that the teaching style of lecturer is 0.016 which means the influence of the teaching style of the lecturer toward the student achievement of $16 \%$. The results showed that: There is a positive and significant effect between teaching styles lecturers towards on the student achievement. There are various styles that arise when the lecturer teaches. The entire personality of the lecturers will be in the spotlight for students while in class. The voice of lecturers when delivering materials, eyes, or movements that can help students to more easily understand the material will greatly help the students. A good teaching style can create a more attractive learning environment for students so as to improve students 'readiness and learning ability (Shaari, 2014). The better the teaching style of the lecturers the better the students' learning achievement. The results of this study are also supported by research conducted by Abanador, Buesa, 
Remo and Mañibo (2014) stated that during lectures involving the movement of lecturers to create a learning environment will encourage positive social interaction, active involvement in learning, and selfmotivation.

\section{Effect of Student Learning Behavior on Student Achievement}

The result of this research is data, calculation of multiple regression analysis showing that learning behavior equal to 0,014 which means the influence of learning behavior toward student's learning achievement equal to $14 \%$. The results showed that there is a positive and significant effect between learning behaviour on student achievement. The results of this study in accordance with the opinion Nazir (2003) states that the number of learning behaviors can be said whether the learning behavior acceptable to the family is low or high. If the learning behavior is high then the learning outcomes of children can be improved.

\section{Conclusion}

1. Teaching style of lecturers and having good learning behavior is one way that can be used to improve student achievement. Planning a good teaching style will make students more eager to learn. Behavior study shown by students can be a reflection of the success of learning.

2. Regression analysis results show that there is a positive and significant influence between teaching styles lecturers and student learning behavior either simultaneously or partially on student achievement.

\section{References}

Abanador, dkk. (2014). "Teaching Methods and Learning Preferences in the Engineering Department of an Asian University". International Journal of Academic Research in Progressive Education and Development. January 2014， Vol.3, No. $1 \quad$ ISSN: 2226-6348

Erdogan, Yavuz. Bayram, Servet. Deniz, Levent. (2008). "Factors That Influence Academic Achievement And Attitudes In Web Based Education". International Journal of Instruction. Vol.1, No.1

Iru, La dan Arihi La Ode Safiun. (2012). "Pendekatan, Metode, Strategi, dan Model- Model Pembelajaran". Yogyakarta : Multi Presindo

Lau, Kung Wong. (2014). “Organizational learning goes virtual? A study of employees' learning achievement in stereoscopic 3D virtual reality". Institute of Textiles and Clothing, The Hong Kong Polytechnic University, Hong Kong.

Lu, Xiaoye. dkk. (2016). "Integration of Histology Lectures and Practical Teaching in China" International Journal of Higher Education. Vol. 5, No. 4; 2016

Mattern, Rebecca. A. (2015). "College Students' Goal Orientations and Achievement". University of Delaware, USA. International Journal of Teaching and Learning in Higher Education

Marmah, Alex Amartei. (2014). "Students' Perception About The Lecture As A Method Of Teaching In Tertiary Institutions. Views Of Students From College Of Technology Eduction, Kumasi (Coltek).

Milligan, Colin dkk. (2014). "Self- Regulated Learning Behaviour In The Finance Industry". Caledonian Academy, Glasgow Caledonian University, Glasgow, UK

Shaari, Abdull Sukor. dkk . (2014). The Relationship Between Lecturer's Teaching Style and Students' Academic engagement. Knowledge-Innovation-Excellence: Synergy in Language Research and Practice.

Procedia - Social and Behavioral Sciences 118 ( 2014 ) $10-20$ 